\title{
Lived Experiences of Incarcerated Mothers
}

\author{
Shella Marcela P. Villanueva \\ University of San Agustin, Iloilo City, Philippines \\ svillanueva@usa.edu.ph \\ Lisa Anna M. Gayoles \\ University of Negros Occidental-Recoletos, Bacolod City, Philippines \\ lisagayoles@gmail.com
}

\begin{abstract}
This study aimed to establish the lived experiences of persons deprived of liberty at the Iloilo City District Jail-Female Dorm, particularly mothers, based on their lived experiences as incarcerated mothers. It utilized the phenomenological research design. Common themes that emerged from the lived experiences of seven incarcerated mothers were drugs as reason for incarceration; inability to perform parental duties; missing family members; financial and encouragement provider; physical absence; religious coping; emotion-focused coping; embracing positive attitude through spirituality; having a happy family by becoming a better person and mother; promising future; and learning from the "inside". These common themes were grouped into five main themes namely: incarceration due to drugs, facing the challenges of motherhood while incarcerated, being strong emotionally and spiritually, maintaining a positive outlook, and being hopeful. The findings suggest implications for collaborative efforts in developing programs for the improvement and sustainability of the well-being of incarcerated women.
\end{abstract}

Keywords: Drugs, Incarceration, Mothers, Phenomenology, Iloilo City, Philippines

Date Submitted: April 2, 2019

Date Revised: July 14, 2019

Date Accepted: July 25, 2019

\subsection{Introduction}

Motherhood is commonly understood as a state of being a mother (Boombeck, 1983). Being a mother involves having a child or children and entails a lot of responsibility (Rabbani-Khorasgani \& Esfahani, 2014). The demands on mothers are endless, yet not all mothers can fulfill their responsibilities due to circumstances such as death, working abroad to provide for the family, or adverse situations that alter family dynamics, such as incarceration. 
Incarceration refers to the confinement of a person or persons in a jail or prison (Reid, 1996). Jail is considered as a secured government institution, which is used to confine an arrested individual while waiting for arraignment or trial, conviction or sentencing, and for those serving short sentences up to a year (Reid, 1996; Glick, 1995; Samaha, 1988). Prisons are for the incarceration of felony offenders for terms longer than a year (Pollock, 2006; Reid, 1996; Samaha, 1988).

Ideally, jails are only for individuals who are waiting for arraignment or trial, conviction or sentencing and will house persons deprived of liberty (PDLs) for a relatively short period. This is not true in the case of Iloilo City District Jail-Female Dorm (ICDJFD). According to Lena (BJMP, 2018), there was a PDL who stayed there for as long as ten years. Thus, as to the length of time of detention, the commonly accepted time of a year or less for jails does not hold true in the Philippines.

There are several purposes of prisons and jails. Jails serve as a place for holding people and as such provide survival services such as food, clothing, and shelter (Samaha, 1988). Prisons are expected to provide health care, work, recreation, education, vocational training and counseling for prisoners because their primary goal is rehabilitation (Luyt, 2008; Samaha, 1988). Convicted offenders are involved in activities designed to make them into law-abiding citizens (Adler, Mueller, \& Loufer, 2007; Reid, 1996).

Criminologists have observed an increasing number of women involved in crimes and found in jails and prisons (Al-Rousan, Rubenstein, Sieleni, Deol, \& Wallace, 2017; Rabbani-Khorasgani \& Esfahani, 2014) in countries such as Brazil (Mendes, Braga, \& Angotti, 2015), in Israel (Shamai \& Kochal, 2008) and in the US (Reid, 1996). In the Philippines, there is an upsurge in the population of prisons and jails brought about by the drug campaign, which started in 2016. It was the year when President Duterte's war on drugs began (De los Santos, 2018). Of this increasing number of women, many are mothers. It was noted that in several countries worldwide, there is an upward trend for incarcerated mothers (Rabbani-Khorasgani \& Esfahani, 2014).

With the increasing number of detainees in the jail as a result of the campaign against drugs, there is increased congestion in Philippine jails (BJMP, 2018). Gharavi, Kashani, Lotfi, Borhani, and Akbarzadeh (2015) noted that the environment is a potential major stressful factor in the formation or aggravation of mental problems. The increased congestion rate entails a greater tendency for mental health problems. According to the data provided by the Bureau of Jail Management and Penology (BJMP, 2018), there are 16 jails in Region VI, one of which is ICDJ-FD. A 392\% congestion rate entails a greater tendency for stress. Left unmanaged, stress may lead to other mental health problems such as depression and anxiety.

There is an increasing literature about the factors that may affect women in prison due to long-term separation, but there seem to be limited studies on the challenges faced by those who are detained temporarily in jail. This research endeavor aimed to determine the mental health of incarcerated women at ICDJ-FD based on their lived experiences. It specifically explored the lived experiences of incarcerated mothers. 


\subsection{Literature Review}

Incarceration is a stressful situation, and jail is an extremely stressful environment. According to the Cognitive Appraisal Theory of Stress, stress and coping are a result of how individuals react to their environment (Lazarus \& Folkman, 1984). A stressful situation is based on a person - environment transaction. It is the transaction of the cognitive processing of an event and one's coping ability (Lazarus, 1990). Cognitive appraisal of an external stressor by the individual influences the positive or negative psychological health outcomes.

Several studies have found that incarceration in a jail or prison environment is a potential stressful factor (Ghavari et al., 2015; Li, Linna, Weimin, Xiaoyan, \& Nanpeng, 2017). Turkish prisoners suffer from depression, anxiety, and stress (Unver, Yuce, Bayram, \& Bilgel, 2013). There is a growing literature about the factors that may affect women in prison like problems brought about by long-term absence because of incarceration, but there seem to be limited studies on the challenges faced by those who are in jail.

The family is the primary institution, which provides for the satisfaction of man's natural needs (Rabbani-Khorasgani \& Esfahani, 2014). It also plays an important role in order for one to be a functioning member of the society (Linonge-Fontebo \& Rabe 2015; Rabbani-Khorasgani \& Esfahani, 2014). It is an implicit belief and practice across cultures that mothers are the primary care takers of children (Linonge-Fontebo \& Rabe, 2015). Incarceration intensely alters the lives of incarcerated men and the women and their children (Turney \& Wildeman, 2018). Parental incarceration is said to have a wide-ranging impact on families such as care and legal custody of children particularly their care arrangement at arrest and imprisonment (Trotter, Flynn, \& Baidawi, 2017). A prison's task is to organize a sentence and at the same time, the institution modifies the practices of being a family by allowing or restricting the relations between family members (Enroos, 2011).

Women increasingly spend time behind bars and, accordingly, they absorb direct consequences of incarceration in addition to the more commonly considered spillover consequences of men's incarceration on families (Turney \& Wildeman, 2018). Most women under the control of the criminal justice system are mothers (Michalsen \& Flavin, 2014). While mothers and non-mothers share some characteristics, they might also differ on some, most notably demographic profile, mental health, and timing of contacts with the criminal justice system. These suggest a need to recognize the diversity among women offender groups.

The consequences of maternal incarceration for three broad aspects of family life are romantic relationships, parenting, and economic well-being (Turney \& Wildeman, 2018). Maternal incarceration is a stressor that proliferates to engender chronic strains in family life. Many of these chronic strains are especially acute when maternal incarceration is accompanied by paternal incarceration. The findings suggest that the stressor of maternal incarceration has reverberating consequences for family life. In various parts of the world, it is reported that there are mothers imprisoned such as in Australia (Luyt 2008; Tabbush \& Gentile, 2013) and Israel (Shamai \& Kochal, 2008). 
Women detained in local jails face challenges that may differ from those who are in a regional or national prison (Rodda \& Belcher, 2017). In jails, the outcome of the case may still be unknown; she may be suffering from substance withdrawal and come up with arrangement for the care of the children. While the children of most male inmates remain in the care of their biological mothers, incarcerated mothers are rarely able to rely on a father whether biological or social, to care for their children (LinongeFontebo \& Rabe, 2015).

In Portugal, mothers, as well as children, are affected by incarceration owing to the mother's actual or presumed central role in child rearing (Granja, da Cunha, \& Machado, 2015). Very few fathers in prison are the primary caretakers of children, whereas many mothers in prison continue to be the primary caretakers (LinongeFontebo \& Rabe, 2015).

Tremblay and Sutherland (2017) noted that there is evidence to suggest that maternal incarceration can have negative implications for children. The authors noted that children are vulnerable to having conduct problems, antisocial behavior, and even at risk of being drop outs in school or encounter academic failures.

Contact between mother and child while incarcerated can affect the child's subjective weathering or well-being. Foster (2015) did a study, which linked the General Strain Theory, criminal justice models of inmate adaptation, and life course stress model. Qualitative and quantitative data were gathered from an incarcerated sample of mothers in a federal prison. Qualitative data were used to identify strains in mothers' lives. The findings showed that deprivation strain of a lack of contact with the mother's minor child is positively associated with her mental and physical health problems and children's subjective weathering. The study recommended that reducing strains mothers face while imprisoned might benefit both inmates and families.

Studies have consistently shown the negative effect of parental incarceration on children, but that greater effect comes from the incarceration of mothers than fathers (Tasca, Turanovic, White, \& Rodriguez, 2014). It also could not be denied that conditions before parental incarceration may influence the impact of incarceration on children left behind rather than incarceration itself.

Hagan and Foster (2012) found that although fathers are incarcerated in much greater numbers than are mothers, the effect threshold is lower, and the scale of effect on educational outcomes tends to be greater for maternal incarceration. The researchers demonstrated both students-and-school-level effects of maternal incarceration. The damaging effects not only affect the children of imprisoned mothers but also spill over to children of non-incarcerated mothers in schools with elevated levels of maternal incarceration. Few children of imprisoned mothers graduated from college while maternal imprisonment effects are found at both student and school levels. The researchers demonstrated these effects based on a large, nationally representative longitudinal study of American children from the 1990s prison generation who were tracked into early adulthood.

Shamai and Kocha (2008) conducted a qualitative study to explore the experience of motherhood among Israeli inmates after they were released. Based 
on in-depth interview with nine women, the study generated five main themes: (a) motherhood is a survival motive; (b) mothers in prison experienced a sense that they have failed somehow; (c) during imprisonment, the mother-child relationship is characterized by coping versus avoidance; (d) being a mother in prison serves as a motive for change; and (e) the transition from questioning the right to be a mother to redeeming motherhood. The five themes were made as a basis for mending motherhood experience. Though being a mother in prison may be traumatic, it could also be an avenue for rehabilitation and growth.

\subsection{Methodology}

We employed the qualitative research design, specifically the phenomenological research design (Tashakkori, Teddlie \& Sines, 2012; Creswell \& Clark, 2015; Field, 2013).

Phenomenology refers to a set of philosophical doctrines loosely sharing assumptions as to what the world is like (ontological), and how it can be known (epistemological), and strategies for the descriptive management of the mental entities relating to such a world. They all strive to capture experiential essences (Hortillas \& Gayoles, 2018). Ontology is concerned with reality. Reality is perceived as a construct dependent to different situations. Epistemology is concerned with "how we know what we know." Epistemology is anchored on the belief that knowledge making is possible through subjective experience and insights. Research that does not have at its core the description of "the things in their appearing," focusing on lived experiences, cannot be considered phenomenological (Hortillas \& Gayoles, 2018).

The Husserlian descriptive phenomenology as a research approach focuses on the data collection, and analysis that pursues logical and scientific consistency by adopting phenomenological strategies must be treated accordingly (Englander, 2012). The main objective of a phenomenological study is to explore the lived experiences of a person, or a group of people, around a specific phenomenon. Human behavior is understood through the eyes of the participants providing a richly textured description of lived experience (Lucerna \& Gayoles, 2018; Piojo, 2015; Moodley, 2009).

Phenomenologists are interested in common features of the lived experiences. Data from only a few individuals who have experienced the phenomenon and who can provide a detailed account of their experience will suffice to uncover its core elements. Phenomenological research is concerned with the meaning and the core lived experience rooted in individuals (Lucerna \& Gayoles, 2018; Degillo, 2017). It encompasses a natural, holistic, and inductive process, where we could study the lived experiences of the incarcerated mothers without manipulating the context. Through this qualitative approach, we attempted to understand a small number of participants' frames of reference, instead of testing preconceived hypotheses on a larger sample.

We set out to obtain information and understanding of the phenomenon of mothers in dealing with their incarceration. With the use of in-depth written narrative stories, we were able to gain knowledge and understanding of this phenomenon. Phenomenology centered on how these incarcerated mothers made sense of their 
experiences; how they transformed their worldview; and how they made sense of their incarceration and transformed their experiences into consciousness (Sailor, 2013).

We were referred to seven incarcerated mothers at the ICDJ-FD. They have a mean age of 36 years old; one is married, two are single, two are separated; one in a live-in relationship, and one is widowed. The number of their children ranged from two to nine. Three of the mothers were college graduates while high school level was the highest educational attainment for the remaining four. All seven incarcerated mothers were involved in non-violent crimes.

Written or oral self-reports, or even aesthetic expression, such as art, narratives, or poetry, can also be evaluated (Lucerna \& Gayoles, 2018; Hortillas \& Gayoles, 2018). We chose to utilize the written narrative stories to obtain knowledge and understanding of these incarcerated mothers.

The validity of narratives of the incarcerated mothers was verified concurrent with the data explication (Hortillas \& Gayoles, 2018). Credibility, fittingness, and auditability were addressed. The incarcerated mothers verified the credibility of my interpretations. Fittingness of the study refers to the probability that the research findings have meaning to others in similar situations. Fittingness needs at least two of the participants to verify. However, all seven incarcerated mothers participated in the verification of data gathered. The incarcerated mothers conducted member checking by reviewing the summary of the descriptions and agreed that the descriptions fitted their experiences. Auditability is evaluating the consistency of qualitative findings. The audit trail was the description of the steps taken from the start of the research to the development and reporting of the findings (Hortillas \& Gayoles, 2018).

Data analysis was done through data explication, which was attained through the analysis of the narratives. It involved bracketing and phenomenological reduction; delineating units of meaning; clustering of units of meanings to form themes; summarizing each narrative story, validating, and modifying them; finding general and unique themes for all the narrative stories and composite summary; and discovering the essence of the lived experiences. (Lucerna \& Gayoles, 2018; Degillo, 2017).

\subsection{Results}

Common themes for the lived experiences of the incarcerated mothers are: drugs as reason for incarceration; inability to perform parental duties; missing family members; financial and encouragement provider; physical absence; religious coping; emotion-focused coping; embracing positive attitude; stay spiritually and emotionally positive; become a better person and mother; happy family; promising future; and learning from the "inside". These common themes were grouped into five main themes, namely: incarceration due to drugs, facing the challenges of motherhood while incarcerated, being strong emotionally and spiritually, maintaining a positive outlook, and being hopeful.

Incarceration due to drugs. Majority of the respondents contended drugs as the reason for incarceration. "Nalulong ako sa droga (I became a drug addict) ". "I was 
caught (drugs), and now I am here in the four corners of ICDS-FD". "I got involved in drugs." "I am here facing the case of RA 9165."

Facing the challenges of motherhood while incarcerated. One of the primary effects of incarceration is the absence of the mother from her family, particularly her children. The respondents shared: "I can't be with them in times they need my supervision and assistance as a mother to them". "Gasakit ang akon buot sa mga adlaw nga dapat ang akon presensya bilang iloy yara sa ila, nainit ako sa kaugalingon ko kung mabalitaan ko nga sila may ginabatyag nga dapat tani atipanon ko sila (I feel hurt particularly on days when they need my presence as a mother; I am angry with myself when I hear that they are sick, and I should be the one taking care of them)". "Struggling for the feeling of being deprived to do the things you want to do for your children for you could not do it for you are physically absent".

These incarcerated mothers miss their children and the opportunity to show their love and care. They realized the importance of the opportunities they had of showing their care to their children now that they are unable to. "I miss the times when I want to hug and kiss them immediately when I want to. I miss the times when we were together." "There are times that I missed them and I wanted to hug them and kiss them but I can't." "Nandiyan parang mabaliw ka sa pangulila sa mahal mo sa buhay (there are times when I felt like going crazy because I miss those I love)."

Even while detained in jail, these incarcerated mothers continued to offer their assistance to the family in the form of encouragement and even financial assistance. "Ginahimo ko gid ang tanan pareho sang pagmasahe, pagmanicure kag ang digamo sa akon isigkapareho para sa bisan gamay lang nga income ko mahatagan ko man sila (I do anything like massage, manicure, and cook for my fellow inmates so that even with a small income I can give to them (children)." "Dahil sa pagmamasashe meron akong source of income. Hindi na kailangan umasa ako sa aking asawa. Maski papano na kakatulong pa ako sa aking pamilya (I get to have some source of income from massaging that I don't need to rely on my husband. I still get to help my family)."

Incarceration entails separation and absence of mothers from their children. These incarcerated mothers consider their physical absence to be a source of anxiety. "During the time when they got sick, I'm so bothered because I can't be with them to be on their side like checking their body temperature and giving their medicines." "Naawa ako sa aking mga anak hindi ko na sila maaruga at makasama (I pity my children because I could not take care of them and be with them)." "Thinking of who would embrace them or hug them if they are sick and not feeling well to make them better... Who would put their blanket on to keep them warm when they feel cold, who would have fixed their rooms and prepare the things they need when they go to school."

Being strong emotionally and spiritually. The respondents find meaning in their experience of incarceration through religion and faith. "All that I do is to pray." "Halos adlaw-adlaw wala gid ako gakalipat sa pagpangamuyo sa Ginoo (almost every day, I do not forget to pray to God." "I have to have faith." "Always trust in the Lord." "I keep myself busy talking to God." "Ang lahat makakaya basta manalig lang ako sa buong may kapal (I can bear anything provided that I have faith and trust in the Almighty God)." 
The respondents learn to be emotionally strong. "Bisan ari ako diri padayon ako nga nagapakabakod sa piyak sang tanan (Even when I am here, I continue to be strong in spite of everything)." "Stay strong for my kids because I still believe that they need me as their mom." "You have to be strong because there is still a family waiting for you outside." "Pirme ko ginahambal stay strong (I always say, stay strong)."

Maintaining a positive outlook. A positive attitude is essential to trust that there is something better in the future. Despite the situation they are in, these incarcerated mothers continue to maintain a positive attitude in life. "Don't think of the case so much and always have a positive outlook in life." "Ang pagpangabuhi diri indi gid man mabudlay basta ang importante himuon talang ang insakto (life here is not that difficult, what is important is to do what is right)." "Focus, and to do the right thing. People around me may talk against me but I won't allow anyone to stop me from changing to becoming a better person." "Ang lahat hindi mahirap kung bukas ang isip mo at puso sa pagbabago (anything is not difficult if you keep an open mind and heart for a change)."

The respondents recognize the importance of being positive spiritually and emotionally. "Always pray and think positive always." "Pray and never give up of becoming a better individual. I know that change is a process and not an event. And change starts from us. Our willingness to change."

Being hopeful. These incarcerated mothers hold on to their wishes of having a happy family. "I will be a better person and mother to my kids." "I can start anew. It is never too late for everything." "Sa akon pamilya, handom ko gid sa ila tanan nga tani padayon lang sila mag intiendihanay kag magpangga-anay sa sulod sang amon panimalay (For my family, I wish for them all to continue to understand and love each other in our household)." They continue to be hopeful for the future of their children. "That they could finish their studies and find work and grow up to God-fearing persons." "I know one day you will all be successful and I will be there to see that and be proud of your achievements."

The respondents have this to say to other incarcerated mothers: "I hope that their realization of being here could help them to become better persons in the coming future." "They should never lose hope and there is a life waiting for them outside." "For women who are here, I am hoping that they might be able to realize, reflect and repent, reform and become a better person for their family especially their children."

\subsection{Discussion}

Engaging in illegal drugs is one of the most common reasons for the incarceration of women in the Iloilo City District Jail. This is consistent with the global trend that when drugs became illegal, this was the primary reason for the increasing number of women who are in jails and prisons (Gunter, Chibnall, Antoniak, Philibert, \& Hollenbeck, 2011; Mahoney, Chouliara, \& Karatzias, 2015). Collier and Friedman (2016) found that in New Zealand, majority of the women they studied reported substance use prior to incarceration. Gunter et al. (2011) on the other hand contended that the 
effects of drug dependence might manifest in depression or anxiety among inmates in community corrections.

Involvement with drugs is one of the reasons for the incarceration of women at ICDJ-FD particularly with mothers who shared their lived experiences. The use of drugs was brought about by the influence of friends and partners.

Being a mother is for life regardless of the situation and age of the children. These incarcerated mothers recognize that incarceration does not change their role as mothers, just the context of their mothering.

One of the mothers said she felt frustrated about her inability to perform her role. These mothers cope with their guilt brought about by their inability to perform their parental function. This is consistent with previous study that women's incarceration has broad social impacts because of the unique caregiving roles that they occupy in their families and communities (Valera, Chang, Hernández, \& Cooper, 2015).

Granja et al. (2015) believe that incarceration deprives mothers the opportunity to perform parental duties and obligations. Mothers feel that due to incarceration they can no longer carry out their role as a parent. Previous studies (Yahyaee, Nooranipoora, Shafiabadia, \& Farzad, 2015; Lucerna, 2017) state that family function ensures the mental health of all members, wherein a dysfunction causes psychological problems such as depression and anxiety.

Rabbani-Khorasgani and Esfahani (2014) found that mothers' delinquency has negatively affected their families. The relationship between mother and child is essential, particularly during the first stages of a child's life. Their study showed that if this relationship is damaged in any way, adverse consequences follow. Women absorb direct consequences of incarceration. Maternal incarceration is a stressor that proliferates to engender chronic strains in family life (Turney \& Wildeman, 2018).

Among the PDLs of ICDJ-FD, their role as a mother is taken over by other members of the family like their own mothers, siblings, or grown up children.

The result of this study is consistent with the findings of Rabbani-Khorasgani and Esfahani (2014) and Schubert, Duininck, and Shlafer (2016), that physical absence from the people, particularly the absence of a mother's love, may bring negative consequences. These negative consequences can affect both mothers and their children.

For incarcerated mothers, higher levels of contact with children especially through letter writing were associated with reduced parenting stress (Loper, Carlson, Levitt, \& Scheffel, 2009). In contrast to inmate mothers, fathers had less contact with children, higher levels of parenting stress, and poorer alliance with caregivers. Inmate mothers miss the physical presence of their loved ones particularly their children, but they continue to maintain this by making use of every opportunity they have to get in touch with these children even just by talking to them through the phone.

Incarcerated mothers gave importance to the benefits of maintaining a relationship with children through physical contact particularly through visitation. The current congestion of the ICDJ-FD resulted in limited visiting period of the PDLs from a 
whole day to an hour a day. In spite of this, mothers maximize the time and opportunity they have to be with their children. De Claire and Dixon (2017) consistently reported positive effects of prisoners receiving visits. Prison visits reduced depressive symptoms in women and adolescent prisoners.

Incarcerated mothers are allowed to earn while in jail to financially assist their family. They provide financial assistance through their income from the projects done inside the jail. This is consistent with the findings of Zerrudo (2017) that mothers continue to earn in order to financially assist their children. Linonge-Fontebo and Rabe (2015) also found that incarcerated mothers continue to be the primary caretakers who continue to provide for the financial needs of their children. PDLs of the ICDJ-FD engaged in beadwork, cross stitching, and bag painting. Several of them have availed of the training provided by TESDA on massage therapy.

Aside from financial help, these incarcerated mothers are also the source of encouragement for their children. They let their children feel that even if they are away they still serve as a source of encouragement for them to strive to become better.

Physical separation of mothers and children may be alleviated by visitation of the children and significant others. According to De Claire and Dixon (2017), prison visits reduced depressive symptoms in women and adolescent prisoners.

These incarcerated mothers have faith that God has a plan for them. This is consistent with the findings of Dye et al. (2014) which suggest that religion ameliorates many pains and problems of imprisonment. Multivariate analyses indicate that religious engagement is indirectly related to prison adjustment. However, the role that religious engagement plays seems to be through helping women deal with feelings of depression.

Dye, Aday, Farney, and Raley (2014) found that irrespective of their religious upbringing, all of their participants agreed that religiosity/spirituality played a key role in their ability to cope with their prison experience. This is further reinforced by the findings of Zerrudo (2017) that in the Philippines, many are believers and attribute the situation they are in to God.

These incarcerated mothers find comfort in God. Being detained in jail entails a lot of uncertainties, as to length of stay, status of the case, and state of the family left behind. Through religion or faith, they find meaning in their lives while incarcerated.

To cope with the depression, anxiety, and stress, the respondents change how they feel. According to Rahimipour Anaraki and Boostani (2014), mothers are affected emotionally by their incarceration. They further found that mothers in their study pointed to their deep psychological problems and sometimes committed suicide due to the separation of their children. However, the incarcerated mothers at the ICDJFD made use of their coping abilities to overcome the negative emotional effects of incarceration. They continue to be steadfast in their belief to be strong for the sake of their children.

According to Cobbina and Bender (2012), most incarcerated adults are optimistic about their chances of success after release. These incarcerated mothers 
recognize that there are things that they could no longer change like what they have done in the past, but they are open to change to a become better person.

In spite of being in jail, these incarcerated mothers continue to be positive in their outlook and find that incarceration gave them the opportunity to reflect and appreciate the things they use to take for granted while they were free. Religious beliefs and faith gave them the strength to go on and give meaning to the event that has happened in their lives.

This is consistent with one of the themes that emerged in the qualitative study of Shamai and Kochal (2008) of incarcerated mothers in Israel. According to Shamai and Kochal (2008), motherhood in prison becomes a motive for change, thus "redeeming their motherhood." These incarcerated mothers viewed incarceration as an opportunity to evaluate their role as a mother before incarceration and how they can change to become better mothers for their children.

These incarcerated mothers continue to be optimistic that good things will happen in spite of the situation they are currently in. This is similar to the findings of Visher and O'Connell (2012) on prisoners' perceptions as they are preparing to leave prison and return to the community that having family support and children increase optimism.

Allen, Flaherty, and Ely (2010) noted that the incarcerated mothers in their study expressed feelings of guilt and remorse for the impact that their behaviors had on their children. However, they expressed hope that their children will have better lives than they did.

These incarcerated mothers remain hopeful. Their hope is evident in their wishes for a better future for their children. This is embodied in their aspirations for their children, in their studies as well as in their other achievements.

Being incarcerated provided the opportunity to reflect on one's life and gave one the chance to change for the better. These incarcerated mothers realized that the time they spent in jail made them realize the need for reform for a better life for themselves and for their children and better reintegration back into society. This is consistent with the findings of Shamai and Kochal (2008) that incarceration provides the opportunity to reflect of the life before incarceration. According to Shamai and Kochal (2008), "being mothers in prison moved them toward mending the experience of motherhood".

Incarceration is found to have generally negative effects on inmates brought about by the loss of their freedom and separation from significant people. Mothers are affected by their inability to perform their parental function due to their physical absence from their children. In spite of the congested condition of the jail, these incarcerated mothers continue to cope, to have a positive outlook, and be hopeful.

\subsection{Conclusion}

These incarcerated women experienced depression attributed to loneliness and sadness. They experienced anxiety associated with some personal concerns. These 
women also experienced stress when compensatory mechanisms are not enough to cope with the consequences of being locked behind bars.

Existing collaboration with different sectors such as religious groups, the academic community services, government, and non-government agencies, have addressed the personal concerns of these incarcerated women, which influenced their mental health. Programs using the psycho-educational approach can enhance the mental health of incarcerated women. These programs should be availed by PDLs, mothers, and non-mothers, to improve their well-being.

In connection to the mental issues of incarcerated women, family members should continue their social, emotional, and financial support for them. Children of incarcerated mothers should be encouraged to regularly visit their mothers.

PDLs at the ICDJ-FD are waiting for the sentencing of crimes they committed. For incarcerated mothers, waiting for the resolution of their cases in jail is a sentence or punishment in itself. For them, "Ang pagka bilanggo, silot." Yet, through this, they continue to be hopeful for a better life for them and their children.

\section{REFERENCES}

Adler, F., Mueller, G. O., \& Loufer, W. S. (2007). Criminology and the Criminal Justice System.6th ed. New York: McGraw Hill

Allen, S., Flaherty, C., \& Ely, G. (2010). Throwaway Moms: Maternal Incarceration and the Criminalization of Female Poverty. Affilia: Journal of Women \& Social Work, 25(2), 160172. https://doi.org/10.1177/0886109910364345

Al-Rousan, T., Rubenstein, L., Sieleni, B., Deol, H., \& Wallace, R. B. (2017). Inside the nation's largest mental health institution: A prevalence study in a state prison system. BMC PublicHealth, 171-179. doi:10.1186/s12889-017-4257-0

Boombeck, E. (1983). Motherhood, the second oldest profession. New York: McGraw-Hill Book Company.

Bureau of Jail Management and Penology (BJMP). (2018). Data and statistics. Retrieved from http://www.bjmp.gov.ph/data/jailpop-pdf

Cobbina, J. \& Bender, K. (2012). Predicting the Future: Incarcerated Women's Views of Reentry Success. Journal of Offender Rehabilitation, 51(5), 275-294. https://doi.org/10.1080/1 0509674.2012.683323

Collier, S. \& Friedman, S. H. (2016). Mental Illness Among Women Referred for Psychiatric Services in a New Zealand Women's Prison. Behavioral Sciences \&The Law, 34(4), 539550. doi:10.1002/bsl.2238

Creswell, J. W. (2015). A concise introduction to mixed methods research. Los Angeles: SAGE.

De los Santos, M. A. (2018, January 8). Congestion at city jail's female dorm continues. The Daily Guardian, pp 1, 7. 
De Claire, K. \& Dixon, L. (2017). The effects of prison visits from family members on prisoners' well-being, prison rule breaking, and recidivism. Trauma, Violence \& Abuse, 18(2), 185199.doi:10.1177/1524838015603209

Degillo, J. L. (2017). Self-confessed substance abusers: A phenomenological study. Master Thesis. University of St. La Salle - Bacolod, Bacolod City, Philippines.

Dye, M. H., Aday, R. H., Farney, L., \& Raley, J. (2014). "The Rock I Cling To": Religious Engagement in the Lives of Life-Sentenced Women. Prison Journal, 94(3), 388-408. doi:10.1177/0032885514537605

Englander, M. (2012). The interview: Data collection in descriptive phenomenological human scientific research. Journal of Phenomenological Psychology, 43, 13-35. doi $10.1163 / 156916212 \times 632943$

Enroos, R. (2011). Mothers in prison: between the public institution and private family relations. Child \& Family Social Work, 16(1), 12-21. doi:10.1111/j.1365-2206.2010.00700.x

Field, A. (2013). Discovering statistics using IBM SPSS statistics and sex and drugs and rock ' $n$ ' roll. Los Angeles: Sage

Foster, H. \& Hagan, J. (2015). Punishment Regimes and the Multilevel Effects of Parental Incarceration: Intergenerational, Intersectional, and Interinstitutional Models of Social Inequality and Systemic Exclusion. Annual Review of Sociology, 41(1), 135-158. doi:10.1146/annurev-soc-073014-112437

Gharavi, M. M., Kashani, H., Lotfi, M., Borhani, M., \& Akbarzadeh, F. (2015). Comparison of depression, anxiety, general mental health and self-esteem among prisoners in consultancy and ordinary wings. Journal of Fundamentals of Mental Health, 17(1), 52-57.http://web.b.ebscohost.com/ehost/

Glick, L. (1995). Criminology. Boston: Allyn \& Bacon

Granja, R., da Cunha, M. P., \& Machado, H. (2015). Mothering from prison and ideologies of intensive parenting: Enacting vulnerable resistance. Journal of Family Issues, 36(9), 1212-1232.doi:10.1177/0192513X14533541

Gunter, T. D., Chibnall, J. T., Antoniak, S. K., Philibert, R. A., \& Hollenbeck, N. (2011). Predictors of suicidal ideation, suicide attempts, and self-harm without lethal intent in a community corrections sample. Journal of Criminal Justice, 39(3), 238-245. doi:10.1016/j. jcrimjus.2011.02.005

Hagan, J. \& Foster, H. (2012). Children of the American prison generation: Student and school spillover effects of incarcerating mothers. Law \& Society Review, 46(1), 37-69. doi:10.1111/j.1540-5893.2012.00472.x

Hortillas, M. L. M., \& Gayoles, L. A. (2018). The Metamorphosis of People Living with Human Immunodeficiency Virus (HIV). Philippine Social Science Journal, 1(1), 9-20. Retrieved from http://philssj.org/index.php/main/article/view/3 
Lazarus, R. S. (1990). Theory-based stress measurement. Psychological Inquiry, 1(1), 3-13.

Lazarus, R. S., \& Folkman, S. (1984). Stress, appraisal, and coping. New York, NY: Springer Publishing Company.

Li, C., Linna, X., Weimin, Y., Xiaoyan, Z., \& Nanpeng, L. (2017). Prevalence and associated factors of alexithymia among adult prisoners in China: A cross-sectional study. BMC Psychiatry, 171-13. doi:10.1186/s12888-017-1443-7

Linonge-Fontebo, H. N., \& Rabe, M. (2015). Mothers in Cameroonian prisons: Pregnancy, childbearing and caring for young children. African Studies, 74(3), 290-309. doi:10.108 0/00020184.2015.1068000

Loper, A. B., Carlson, L. W., Levitt, L., \& Scheffel, K. (2009). Parenting stress, alliance, child contact, and adjustment of imprisoned mothers and fathers. Journal of Offender Rehabilitation, 48(6), 483-503. doi:10.1080/10509670903081300

Lucerna, E., \& Gayoles, L. A. (2018). The Effect of Pastoral Counseling on the Psycho-Spiritual Well-Being of Seminarians. Philippine Social Science Journal, 1(1), 21-40. Retrieved from http://philssj.org/index.php/main/article/view/7

Luyt, W. M. (2008). Imprisoned mothers in South African prisons with children outside of the institution. European Journal of Crime, Criminal Law \& Criminal Justice, 16(3), 299-323. doi:10.1163/157181708X333364

Mahoney, A., Chouliara, Z., \& Karatzias, T. (2015). Substance related offending behavior programme (SROBP): An exploration of gender responsivity and treatment acceptance issues for female prisoners. Journal of Forensic Psychiatry \& Psychology, 26(6), 798-823. doi:10.1080/14789949.2015.1062993

Mendes Braga, A. G. \& Angotti, B. (2015). From hyper-maternity to hypo-maternity in women's prisons in Brazil. Sur: Revistalnternacional De DireitosHumanos, 12(22), 221-231.

Michalsen, V., \& Flavin, J. (2014). Not all women are mothers: addressing the invisibility of womenunder the control of the criminal justice system who do not have children. Prison Journal, 94(3), 328-346. doi:10.1177/0032885514537600

Moodley, J. (2009). An interpretive phenomenological analysis of the effects of burnout as experienced by volunteer lay counsellors (VLCS). MA Clinical Psychology Dissertation, Department of Psychology, University of Pretoria, South Africa. Retrieved from http:// upetd.up.ac.za/thesis/available/etd-09272010-185850/unrestricted/dissertation.pdf

Piojo, A. L. (2015). The relationship between the predissolution self-expansion and the post dissolution self-concept of women after annulment of marriage. PhD Dissertation. Recoletos de Bacolod Graduate School, University of Negros Occidental Recoletos, Bacolod City, Philippines.

Pollock, J. M. (2006) Prisons: Today and Tomorrow. 2nd ed. Boston: Jones \& Bartlett Publishers

Rabbani-Khorasgani, A. \& Esfahani, H. R. (2014).A qualitative study of family influence on women's delinquency (The Case of female prisoners in Isfahan's Central Jail).Security \& 
Social Order Strategic Studies, 8(2), 19-37.Retrieved from http://web.b.ebscohost.com/ ehost/pdfviewer/pdfviewer?vid

Rahimipour Anaraki, N. \& Boostani, D. (2014). Living in and living out: A qualitative study of incarcerated mothers' narratives of their children's living condition. Quality and Quantity, 48(6), 3093-3107.

Reid, S. T. (1996). Criminal justice, 4th ed. United States of America. Brown and Benchmark Publishers

Rodda, J., \& Beichner, D. (2017). Identifying programming needs of women detainees in a jail environment. Journal of Offender Rehabilitation, 56(6), 373-393.doi:10.1080/105096 74.2017.1339161

Sailor, J. L. (2013). A phenomenological study of falling out of romantic love. The Qualitative Report, 18(Art. 37), 1-22. Retrieved from http://www.nova.edu/ssss/QR/QR18/ sailor37.pdf

Samaha, J. (1988). Criminal justice. St. Paul: West Publishing Company

Schubert, E. C., Duininck, M., \& Shlafer, R. J. (2016). Visiting mom: A pilot evaluation of a prisonbased visiting program serving incarcerated mothers and their minor children. Journal of Offender Rehabilitation, 55(4), 213-234. doi:10.1080/10509674.2016.1159641

Shamai, M. \& Kochal, R. (2008). "Motherhood starts in prison": The experience of motherhood among women in prison. Family Process, 47(3), 323-340. doi:10.1111/j.15455300.2008.00256.x

Tabbush, C. \& Gentile, M. F. (2013). Emotions behind bars: The regulation of mothering in Argentine jails. Signs: Journal of Women in Culture \& Society, 39(1), 131-149.

Tasca, M., Turanovic, J. J., White, C., \& Rodriguez, N. (2014). Prisoners' assessments of mental health problems among their children. International Journal of Offender Therapy \& Comparative Criminology, 58(2), 154-173. doi:10.1177/0306624X12469602

Tashakkori, A, Teddie, C. \& Sines, M.C. (2012). Mixed methods in psychological research. In Weiner, O., Shinka J.A. \&Velicer, W.F. (Eds). Handbook of psychology $\left(2^{\text {nd }} e d\right)$, Volume 2 (Research methods in psychology). Wiley

Tremblay, M. \& Sutherland, J. (2017). The Effectiveness of parenting programs for incarcerated mothers: A systematic review. Journal of Child \& Family Studies, 26(12), 3247-3265. doi:10.1007/s10826-017-0900-8

Trotter, C., Flynn, C., \& Baidawi, S. (2017). The impact of parental incarceration on children's care: identifying good practice principles from the perspective of imprisoned primary carer parents. Child \& Family Social Work, 22(2), 952-962. doi:10.1111/cfs.12315

Turney, K. \& Wildeman, C. (2018). Maternal incarceration and the transformation of urban family life. Social Forces, 96(3), 1155-1181. doi:10.1093/sf/sox070 
Unver, Y., Yuce, M., Bayram, N., \& Bilgel, N. (2013). Prevalence of depression, anxiety, stress, and anger in Turkish prisoners. Journal of Forensic Sciences (Wiley-Blackwell), 58(5), 12101218. doi:10.1111/1556-4029.12142

Valera, P., Chang, Y., Hernández, D., \& Cooper, J. (2015). Exploring kinship and social support in women with criminal justice backgrounds. Journal of Offender Rehabilitation, 54(4), 278-295. doi:10.1080/10509674.2015.1025178

Visher, C. A. \& O'Connell, D. J. (2012). Incarceration and inmates' self perceptions about returning home. Journal of Criminal Justice, 40(5), 386-393. https://doi.org/10.1016/j. jcrimjus.2012.06.007

Yahyaee, G. A., Nooranipoora, R., Shafiabadia, A., \& Farzad, V. (2015). The effectiveness of transactional analysis group-counseling on the improvement of couples' family functioning. Retrieved from http://jhygiene.muq.ac.ir/article-1-42-en.pdf

Zerrudo, M. R. A. (2017). Freedom in prison: Prison in freedom. Paper presented at the 4th National Research Conference, Philippine Criminal Justice Researchers Society, University of Cebu, Lapu-Lapu \& Mandaue City 